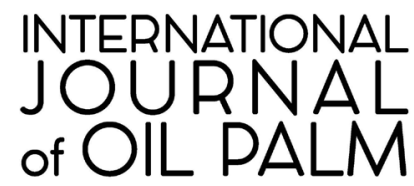

Volume 1, Number 1, January 2018

Page 1-9

ISSN: 2599-3496 print

ISSN: 2614-2376 online

\title{
A Rapid Inoculation Method for Infection of Ganoderma in Oil Palm
}

\author{
Maria Indah Purnamasari', Delia Agustina ${ }^{1}$, Cahya Prihatna1, \\ Antonius Suwanto ${ }^{*}$ \\ ${ }_{1}^{1}$ PT Wilmar Benih Indonesia, Cikarang 17530, Indonesia \\ ${ }^{2}$ Bogor Agricultural University, Bogor 16680, Indonesia
}

\begin{abstract}
Basal stem rot (BSR) is a major disease of oil palm plantation caused by pathogenic fungus Ganoderma boninense. To overcome the disease, development of resistant or tolerant oil palms is crucial for sustainable production of palm oil. Thus a reliable and rapid method to assess resistance of oil palm to BSR is important. Here we report an inoculation technique designated as mycelium inoculation technique. This method is faster and simpler compared to the traditional technique using rubber wood block. The technique that we developed results in consistency of infection and disease can be evaluated as early as two weeks after inoculation with $G$. boninense. Furthermore, this method is also able to differentially assess resistant and susceptible palm seedlings to BSR. The results show that this new inoculation technique can be used as a routine method to infect oil palm seedlings and can be utilised for development of resistant cultivar of oil palm to $G$. boninense.
\end{abstract}

Keywords: basal stem rot, Elaeis guineensis, mycelium, rubber wood blocks, tolerant

\section{INTRODUCTION}

Oil palm (Elaeis guineensis) is a perennial crop cultivated in several tropical countries and is the most efficient producer of vegetable oil (palm oil) compared with other oil-producing plants. The expansion of oil palm industry began in 1990s and in 2005/2006, Indonesia became the largest producer of palm oil in the world after Malaysia. However, the BSR disease is becoming a major obstacle to the production and sustainabili- ty of oil palm plantations. For more than 50 years, the disease has caused serious damage to oil palm plantations in Indonesia and Malaysia. BSR disease causes a decrease in fresh fruit bunch (FFB) weight, stem weight to oil palm bunch and eventual death of the plant (Susanto 2002; Susanto et al. 2005).

Various attempts have been made to control $G$. boninense attacks which include mechanical, chemical and biological controls. However, no satisfactory results have been reported (Susanto 2002). One of the reasons why this pathogen is diffi-

\footnotetext{
${ }^{*}$ Corresponding author:

Department of Biology, Faculty of Mathematics and Natural Sciences,

Dramaga Campus, Bogor Agricultural University, Bogor 16680, Indonesia

E-mail: asuwanto@indo.net.id
} 
cult to control is because it is a soil borne pathogen that spreads and survives in soil. Moreover, the external symptoms of BSR is also difficult to detect at the early stage of infection. The common practices to limit spread of BSR usually involve methods that target sanitation such as soil mounding, isolation through trenching, and removal of diseased plant debris from plantation area. Chemical control through the use of fungicides was reported to be ineffective to control the disease (Chung 2011).

Another approach to control BSR is through breeding and the use of plants that are resistant or tolerant to G. boninense. However, there are constraints to the development of resistant oil palm through plant breeding. The mechanisms underpinning $G$. boninense pathogenicity and the defence response of plants are still poorly understood. This is exacerbated by the lack of simple bioassay of BSR in oil palms. For example, inoculation methods that will allow rapid and simple evaluation of BSR disease are still lacking. Naturally, infection of $G$. boninense and the progression of BSR symptoms in mature plants are slow (Panchal \& Bridge 2005; Rees et al. 2009). This poses a challenge to screen cultivars resistant to BSR. Currently, the most commonly used artificial inoculation of $G$. boninense is using colonized rubber wood block (RWB) (Lim et al. 1992; Idris et al. 2004). This method has been utilized as a standard technique of inoculation in research of BSR disease. However, this method is laborious and time-consuming. A typical RWB inoculation requires at least six months from preparation until disease evaluation (Chong et al. 2012). Due to the long incubation period and difficulty in sterilizing $\mathrm{RWB}$, contamination rate of other fungi is quite high. Therefore, the objective of this study is to develop a rapid, reproducible, and simple inoculation technique that can be used routinely for in planta assessment of BSR disease in oil palm.

\section{MATERIALS AND METHODS}

\section{Ganoderma boninense Isolates and Oil Palm Cultivars}

Ganoderma boninense used in this study was isolate B29 originated from oil palm plantations in West Sumatera (Purnamasari et al. 2012). Oil palm seedlings used were tenera (dura $x$ pisifera) cultivars which were our collection (Research and Development PT Wilmar Benih Indonesia) and one cultivar (MT Gano) that was obtained from PT Socfin Indonesia (Table 1). Seedlings used were germinated seeds and acclimatized, tissue-culture-generated plantlets (ramets).

\section{Inoculation of Ganoderma boninense}

Artificial inoculation of $G$. boninense was performed using mycelium inoculation technique (Chong et al. 2012) with some modifications. Inoculum of $G$. boninense B29 was prepared by cutting mycelia of 6-day-old culture on potato dextrose agar (PDA) into $1 \times 1 \mathrm{~cm}^{2}$ plugs using a sterile inoculated into $100 \mathrm{~mL}$ potato dextrose scalpel. The mycelial plugs

Table 1 Oil palm cultivars used in this study

\begin{tabular}{lll}
\hline Cultivar & Type & Source \\
\hline TS1 & Seedlings & Wilmar \\
TC17 & Tissue culture & Wilmar \\
TC20 & Tissue culture & Wilmar \\
TC68 & Tissue culture & Wilmar \\
TC39 & Tissue culture & Wilmar \\
TC57 & Tissue culture & Wilmar \\
TC24 & Tissue culture & Wilmar \\
TC27 & Tissue culture & Wilmar \\
TC18 & Tissue culture & Wilmar \\
MT Gano & Seedlings & Socfindo \\
\hline
\end{tabular}


were then broth (PDB) and incubated for 4 days at $28{ }^{\circ} \mathrm{C}$ with agitation. After 4 days, the mycelium cultures were blended using a sterile hand held blender (Philips ${ }^{\circledR}$ HR1603) for 3 minutes with the addition of $0.002 \%$ Tween $^{\circledR} 20$. The concentration of mycelia was adjusted to $10^{5}$ fragments $\mathrm{mL}^{-1}$ using a haemocytometer.

For oil palm seedlings, roots of 4-month-old oil palm plants were removed carefully from soil and soaked in the mycelium suspension for 30 minutes before replanting. As a control, plant roots were immersed in sterile water for 30 minutes. The inoculated plants were then replanted in sterile soil in 70-mm pots and grown in glasshouse. Soil was sterilized using an autoclave with liquid cycle $\left(121^{\circ} \mathrm{C}, 20\right.$ minutes, $100 \mathrm{kPa}$ ) then put at room temperature for 2 days. After 2 days, the soil was sterilized again with the same conditions prior to potting. Plants in pots were placed in a greenhouse with ambient relative humidity (ranges between 70 and $90 \%$ ), kept at $30{ }^{\circ} \mathrm{C}$, watered twice daily and fertilized once a week [8 $\mathrm{g} 0.625 \mathrm{~g} \mathrm{~L}^{-1}$ of $N: P: K: M g$ (15:15:6:4) fertilizer for 100 seedlings]. The progression of disease symptoms was observed every week. For each line of seedling, ten plants were used for this test and each plant was planted in one pot. For ramets, the plantlets were acclimatized for 2.5 months prior to inoculation with $G$. boninense. After acclimatization, the ramets were inoculated using the same methods as for the germinated seedlings.

\section{Evaluation and Assessment of Basal Stem Rot Disease}

After two weeks of incubation, disease was evaluated and scored. Disease scoring was measured on a scale of 0-4 according to the observed symptoms of the disease, where $0=$ healthy plants; $1=$ slightly chlorotic spots on the leaves; $2=$ chlorosis in 1-2 leaves; $3=$ chlorosis on many leaves (> 2 leaves); 4 = dead plants (Abdullah et al. 2003).

The disease ranking is an ordered categorical (ordinal) variable that has non-Gaussian distribution, thus the statistical model applied was non-parametric. Statistical test was conducted using a general linear model to compare significance of scores between cultivars and probabilities were adjusted further by using a Tukey post-hoc test $(P<0.05)$. Statistical analysis was conducted using the $\mathrm{R}$ statistics program ( $\mathrm{R}$ Core Team 2016).

\section{Verification of Ganoderma boninense Infection}

To ensure that the observed symptoms of BSR was caused by G. boninense B29, the pathogen was re-isolated from the infected roots and molecular tests were performed to identify the isolated fungus. Roots of healthy (control) and diseased oil palms were cut, washed with water and surface-disinfected using $1 \%(\mathrm{v} / \mathrm{v})$ sodium hypochlorite solution for 5 minutes then rinsed using sterile distilled water. Each root piece was then grown on Ganoderma selective medium (Chong 2010) and incubated at $30{ }^{\circ} \mathrm{C}$ for one week.

After one week of incubation, observation was made on the fungi that grew around the infected roots. These fungal colonies were re-isolated and grown on PDA for six days. Mycelia that grew on the media were collected and genomic DNA was extracted using DNeasy Plant Mini Kit (Qiagen). Fungal identification was performed by analyzing DNA sequences in the internal transcribed spacer region I (ITSI), region II (ITSII), and the 5.8S ribosomal DNA (rDNA). DNA sequences within these regions (ITSI, ITSII, and 
5.8S rDNA) were amplified using the universal primers ITS1 (5'-TCCGTAGGTGAACCTGCGG-3') and ITS4 (5'-TCCTCCGCTTATTGATATGC-3'). The amplified DNA fragments were then sequenced (Applied Biosystems ${ }^{\circledR} 3130$ Genetic Analyzer, Thermo Scientific) and verified.

\section{RESULTS AND DISCUSSION}

\section{Mycelium Inoculation Technique Pro- vides a Rapid and Consistent Patho- genicity Test}

The mycelium inoculation technique developed in this study has enabled a rapid and simple infection of $G$. boninense into oil palm seedlings. Symptoms of BSR disease began to appear a week after inoculation. After two weeks, BSR symptoms in the crowns and leaves have progressed significantly as shown by necrotic crowns and leaves, severe wilting, and rotten stems, especially at the base (Figure 1). Longitudinal sections of the stem of inoculated plants revealed browning and rotten crowns, whereas healthy plants did not show these symptoms.

In addition, root observations showed that plants with necrotic and rotten stems also exhibited root rot (Figure 2). Mycelial colonization was also observed in infected plants especially at the root area. In contrast, uninoculated plants were healthy and did not show symptoms of BSR disease. Based on the observed BSR symptoms, there was no difference between the plants originating from tissue culture (ramet) and seedlings.

The technique was also capable of differentiating the levels of tolerance or susceptibility of several cultivars of oil palms including cultivars in which the tolerance levels are already known (TS1 and MT Gano). This technique was developed based on a simple hypothesis that $G$. boninense, like some other plant pathogens, will be able to infect plants even though it is grown on defined media and inoculated artificially. Using this inoculation technique, the whole process only took 24 days, 10 days to grow G. boninense culture and 14 days for bioassay of BSR disease. The technique was much faster than the standard method that uses RWB that typically takes about six months until the disease can be assessed. The differences between these two methods are summarized in Table 2.

Mycelium inoculation employed in our study was more effective because there was direct contact between pathogen and plant roots. In the rubber wood block technique, direct contact between plant roots and the pathogen is crucial in successful infection compared to the size of the wood block used (Rees et al. 2007). In our method, because roots were dipped into the mycelial suspension, it ensured direct contact between roots and the pathogen. In addition, the method also gave faster results than a method reported in a previous study conducted by Chong et al. (2012) where detection of ergosterol concentration in inoculated plants takes 3-6 weeks after inoculation.

Table 2 Comparison of mycelium inoculation methods and rubber wood blocks

\begin{tabular}{lll}
\hline Parameters & $\begin{array}{l}\text { Mycelium } \\
\text { inoculation } \\
\text { technique } \\
\text { (this study) }\end{array}$ & $\begin{array}{l}\text { Rubber wood } \\
\text { block }\end{array}$ \\
\hline $\begin{array}{l}\text { Time to prepare } \\
\text { inoculum }\end{array}$ & 10 days & 1 month \\
$\begin{array}{l}\text { Incubation time } \\
\text { Inoculum } \\
\text { concentration }\end{array}$ & $\begin{array}{l}\text { 2 weeks } \\
\text { Quantified }\end{array}$ & $\begin{array}{l}\text { Not quantified } \\
\begin{array}{l}\text { Risk of } \\
\text { contamination } \\
\text { Levels of complexity } \\
\text { in preparation }\end{array}\end{array}$ \\
\hline
\end{tabular}




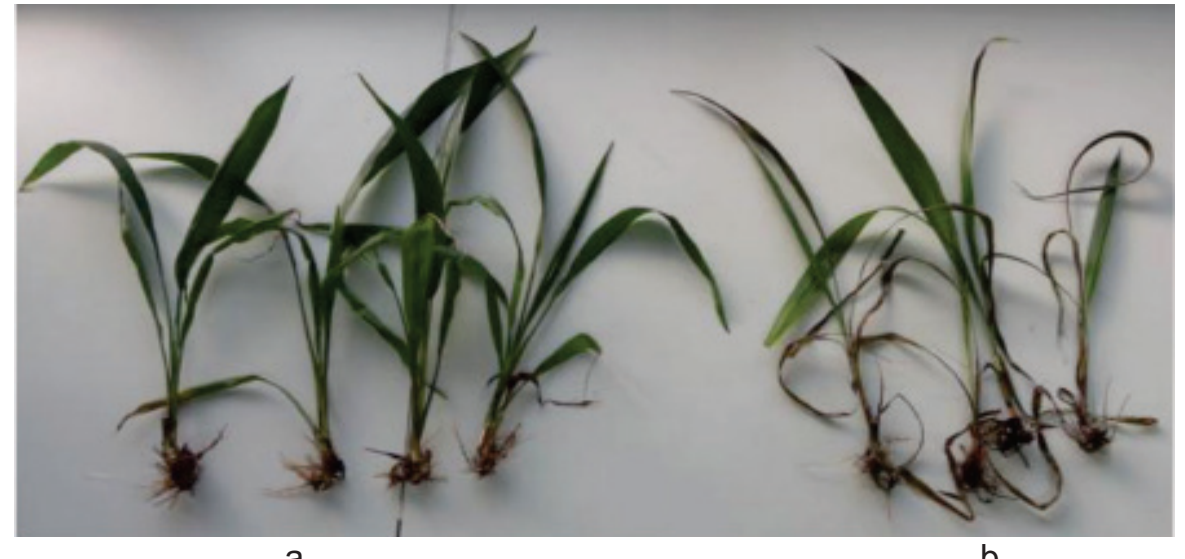

a

b

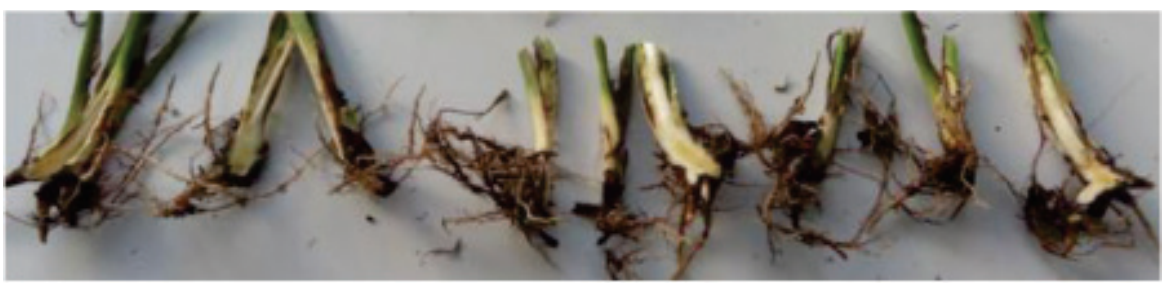

C

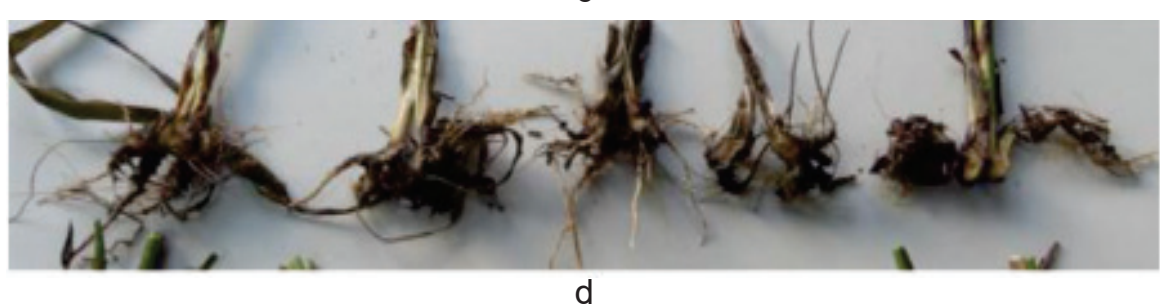

Figure 1 Symptoms of basal stem rot disease in tolerant (a and c) and susceptible plants (b and d) to Ganoderma boninense. Inoculation of $G$. boninense was performed using mycelium inoculation technique. a Leaves and stems of tolerant plants did not show symptoms of basal stem rot (BSR) disease, b while necrotic tissues were seen in susceptible plants $c$ longitudinal slice of healthy and d infected stems.

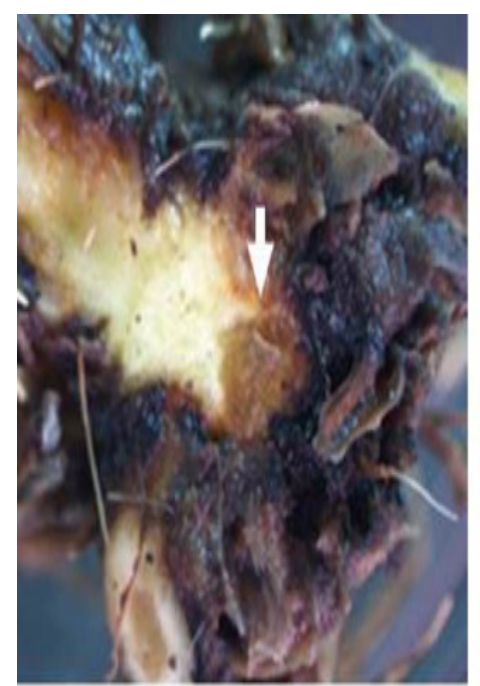

a

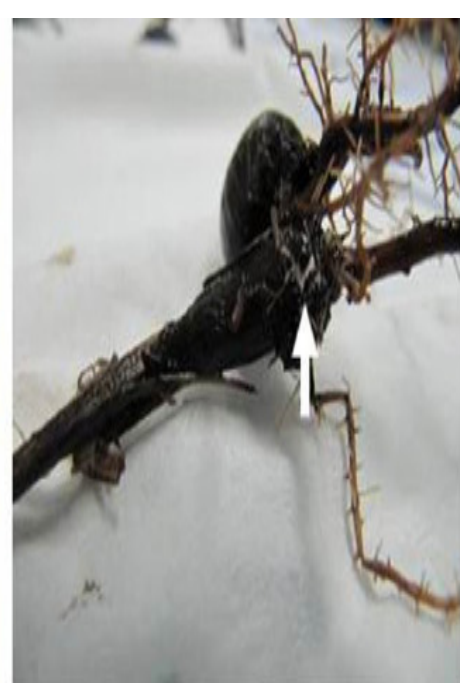

b

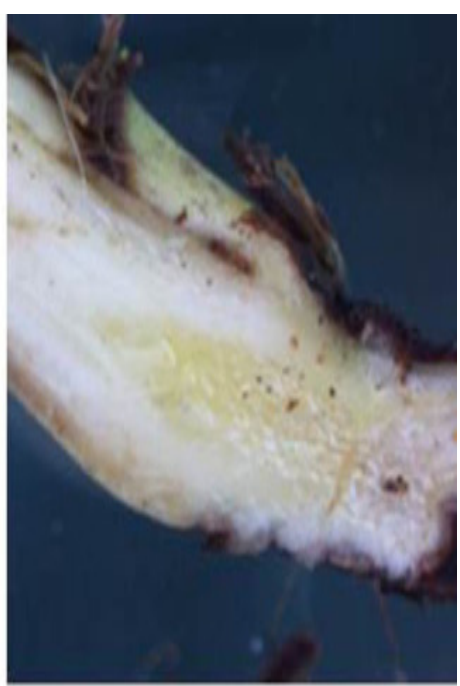

C

Figure 2 Necrotic and rotten crown of an infected plant a as indicated by the arrow. b Colonization of mycelia at the base of the infected stem (arrow). c Longitudinal section of crown of a healthy plant. 
This is because the mycelium inoculation method used immersion technique that allowed longer contacts between mycelia and plant roots than the spray method used by Chong et al. (2012).

Another important factor is that in this study, in contrast to the rubber wood block technique, concentration of inoculum was determined and quantified. Concentration of $10^{5}$ mycelia $\mathrm{mL}^{-1}$ of $\mathrm{G}$. boninense was sufficient to infect plant roots and provided consistent pathogenicity levels. Considering that $G$. boninense is a weak competitor in the soil (Idris et al. 2004), the determination of quantifiable concentration of inoculum becomes crucial to the effectiveness of infection.

\section{The Mycelium Inoculation Technique was Able to Differentiate Tolerance of Oil Palms to Basal Stem Rot Disease}

Evaluation of tolerance or susceptibility levels of oil palm lines was observed two weeks after inoculation. Among ten different cultivars tested, it was shown that TS1, TC27, and TC18 had the highest number of diseased plants showing high were susceptible to $G$. boninense (Figure 3). Cultivars TC24 and TC18 were also susceptible to $\mathrm{G}$. boninense even though the proportion of the diseased plants was not as high as the three cultivars mentioned above. On the other hand, TC20, TC68, and MT Gano cultivars showed the lowest number of diseased plants, which means that these cultivars were tolerant to $G$. boninense. Meanwhile, TC17 and TC39 also showed tolerance to G. boninense although it was not as strong as TC20, TC68, and MT Gano.

Based on the differences in the disease severity, statistical test showed that the plants could be considered into three groups: susceptible (TS1, TC27, TC18), moderate tolerant (TC57, TC24), and tolerant (TC17, TC20, TC39, and MT Gano) (Figure 4). Amongst the tolerant group, TC20, TC68, and MT Gano were the most tolerant cultivars to $G$. boninense. The division of tolerance and susceptibility was solely based on our statistical interpretation of the data since there is no comprehensive reference on the classification of tolerance in oil palms in the current literature.

The effectiveness of mycelium inoculation technique was tested using a number of oil palm cultivars originated from both seedlings and tissue culture clonals. The consistency of $G$. boninense pathogenic-

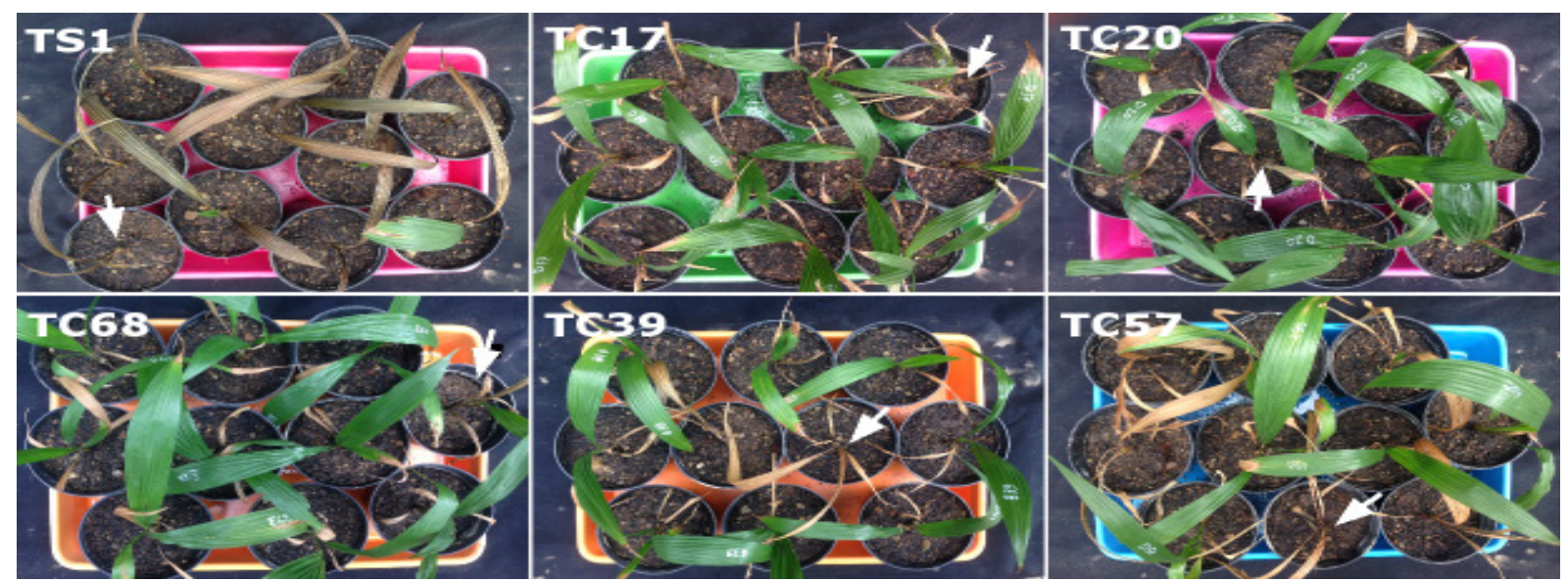

Figure 3 Pathogenicity test of Ganoderma boninense B29 on several oil palm cultivars for selection of tolerant cultivars using mycelium inoculation technique developed in this study. Examples of infected and necrotic plants are shown by white arrows. 
ity in both types of oil palm materials indicated that this method can be used for plants of various origins. In addition to consistency, the bioassay also produced the expected levels of tolerance or susceptibility in some of the cultivars. For example, TS1 is known to be susceptible to $G$. boninense and the results confirmed the susceptibility of TS1. In contrast, MT Gano was tolerant to $G$. boninense, consistent with the report released by PT
Socfin Indonesia, the company that produces the cultivar.

\section{Molecular Analysis Confirmed that Infection in the Plants was Caused by Ganoderma boninense}

Isolation of the fungi from the infected root showed that the fungal isolates were morphologically the same as G. boninense B29 (Figure 5). Sequencing of the ITS regions of these isolates showed sim-

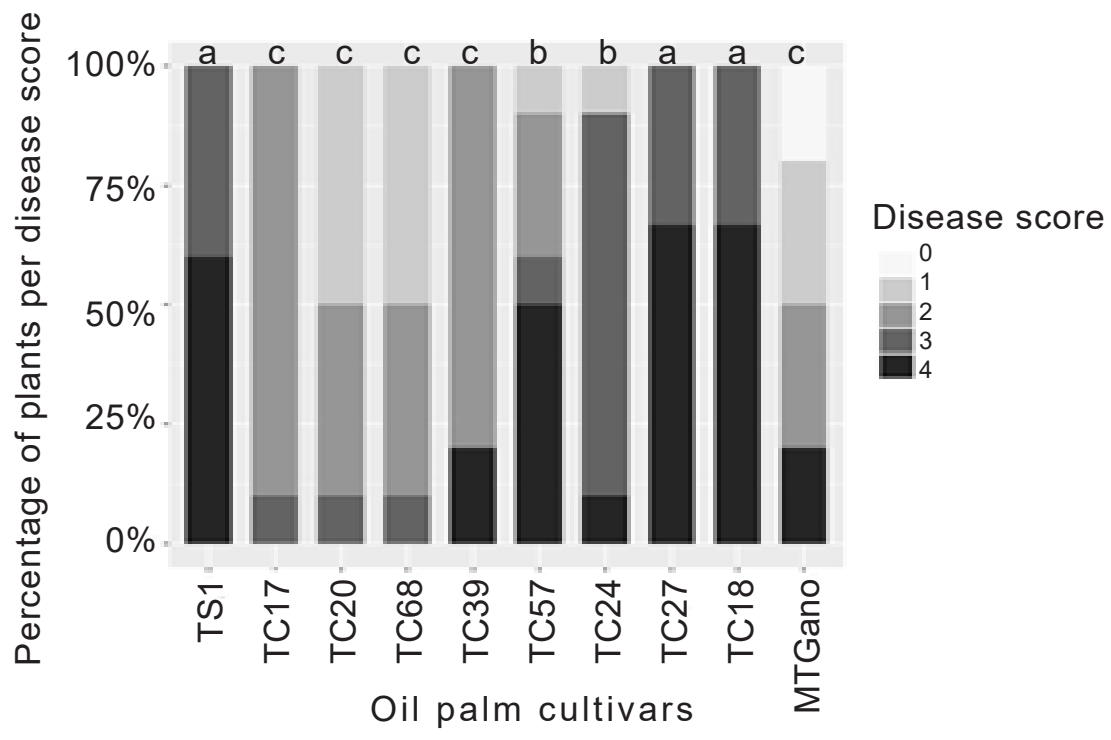

Figure 4 Basal stem rot (BSR) disease assessment in several oil palm cultivars inoculated with Ganoderma boninense B29 using mycelium inoculation technique. Disease scoring of BSR wilt according to Abdullah et al. (2003) at two weeks after inoculation. The area for each colour code indicates the percentage of plants having the corresponding disease scores. At least ten plants with each plant in individual pot were used in this assay. Control is non-inoculated plants treated only with water. Bar charts labelled with different letters indicate significant differences $(P<0.05)$.

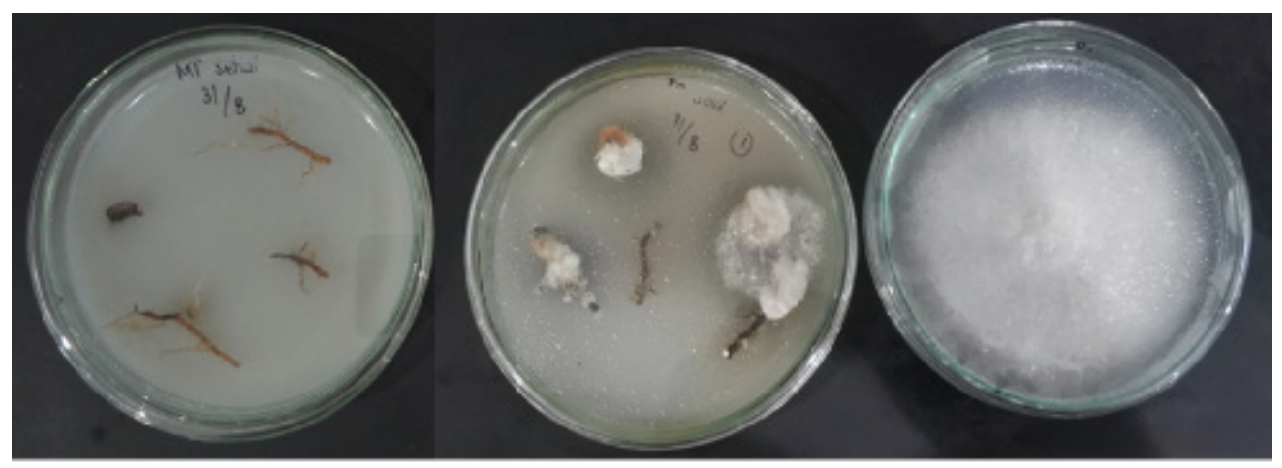

a b C

Figure 5 Re-isolation of Ganoderma boninense B29 from roots of infected plants. a Plant roots inoculated onto Ganoderma selective medium (GSM). b Mycelia of $G$. boninense from infected roots began to grow on the medium. c Pure culture of $G$. boninense isolated from the infected roots. 
ilarities with the published sequences of G. boninense (95.4\% similarity) (data not shown).

Together, results presented here suggest that the new inoculation method can assist plant breeding process by selecting resistant or tolerant cultivars of oil palms to $G$. boninense. It also can assist other bioassays such as application of synthetic or organic fungicides to control BSR thus allowing assessment of efficacy of the fungicides. Further, the rapid and reproducible in planta assay of disease tolerance would be useful for identifying and functional analyses of genes that could play role in tolerance of oil palm to $G$. boninense.

\section{CONCLUSION}

In conclusion, a new inoculation technique was developed to facilitate rapid and reliable infection of $G$. boninense B29 into oil palm. In planta disease assays showed that the BSR disease produced by this method was reproducible and it required a shorter incubation time with simpler preparation compared with the existing method of inoculation such as RWB. In addition, the consistency of this technique was further confirmed in the assessment of BSR in several cultivars of oil palm with different levels of tolerance to G. boninense.

\section{REFERENCES}

Abdullah F, Ilias GNM, Nelson M, Izzati NAMZ, Yusuf UK. 2003. Disease asessment and the efficacy of Trichoderma as a biocontrol agent of basal stem rot of oil palms. Res Bull Sci Putra. 11:31-33.

Chong KP. 2010. The role of phenolics in the interaction between oil palm and Ganoderma boninense the casual agent of basal stem rot (Thesis). Semenyih (ML)/Nottingham (UK): Univ Nottingham.

Chong KP, Atong M, Rossall S. 2012. The role of syringic acid in the interaction between oil palm and Ganoderma boninense, the causal agent of basal stem rot. Plant Pathol. 61(5):953-963.

Chung G. 2011. Management of Ganoderma diseases in oil palm plantations. Planter. 87(1022):325-339.

Idris A, Kushairi A, Ismail S, Ariffin D. 2004. Selection for partial resistance in oil palm progenies to Ganoderma basal stem rot. J Oil Palm Res. 16(2):12-18.

Lim TK, Chung GF, Ko WH. 1992. Basal stem rot of oil palm caused by Ganoderma boninense. Plant Pathol Bull. 1(3):147-152.

Panchal G, Bridge PD. 2005. Following basal stem rot in young oil palm plantings. Mycopathologia. 159(1):123-127. Purnamasari MI, Prihatna C, Gunawan AW, Suwanto A. 2012. Isolasi dan identifikasi secara molekuler Ganoderma spp. yang berasosiasi dengan penyakit busuk pangkal batang di kelapa sawit. J Fitopatol Indones. 8(1):9-15. DOI: 10.14692/jfi.8.1.9.

Rees RW, Flood J, Hasan Y, Cooper RM. 2007. Effects of inoculum potential, shading and soil temperature on root infection of oil palm seedlings by the basal stem rot pathogen Ganoderma boninense. Plant Pathol. 56(5):862870.

Rees RW, Flood J, Hasan Y, Potter U, Cooper RM. 2009. Basal stem rot of oil palm (Elaeis guineensis); mode of root infection and lower stem invasion by Ganoderma boninense. Plant Pathol. 58(5):982-989.

Susanto A. 2002. Kajian pengendalian hayati Ganoderma boninense Pat. 
penyebab penyakit busuk pangkal batang kelapa sawit (Dissertation). Bogor (ID): Institut Pertanian Bogor.

Susanto A, Sudharto PS, Purba RY. 2005. Enhancing biological control of basal stem rot disease (Ganoderma bonin- ense) in oil palm plantations. Mycopathologia. 159(1):153-157.

Team. 2016. R: a language and environment for statistical computing. R Foundation for Statistical Computing. Vienna (AT): R C Austria. 